\title{
The effects of cage type, oviposition time and egg storage period on the egg quality characteristics of laying hens
}

\author{
Ines TABIB ${ }^{1, a, ®}$, Esin Ebru ONBAŞILAR ${ }^{1, b}$, Suzan YALÇIN ${ }^{2, c}$ \\ ${ }^{1}$ Ankara University, Faculty of Veterinary Medicine, Department of Animal Husbandry, Ankara; ${ }^{2}$ Selçuk University, Faculty of \\ Veterinary Medicine, Department of Food Hygiene and Technology, Konya, Turkey. \\ ${ }^{\mathrm{a}} 0000-0001-6555-0386$; b0000-0002-1321-0280; ${ }^{\mathrm{c}} 0000-0002-3937-6705$. \\ $\square$ Corresponding author: tabibines@yahoo.fr \\ Received date: 11.08.2020 - Accepted date: 21.12.2020
}

\begin{abstract}
Egg has valuable nutrients however; these nutrients may be affected by many factors. In this study, it was aimed to determine the effects of cage type, oviposition time and egg storage period on egg quality characteristics of laying hens. A total of 410 eggs were collected from unenriched and enriched cages in the morning and in the afternoon. After the eggs were weighed, they were stored at $21^{\circ} \mathrm{C}$ and $20 \%$ relative humidity until the $30^{\text {th }}$ day of storage. It was determined that unenriched cage eggs had higher in shell breaking strength, albumen ash and $\mathrm{pH} \&$ lipid of yolk and lower egg weight loss, yolk index \& yolk color compared with enriched cage eggs. Morning eggs had the highest egg weight loss and the lowest egg weight, yolk height and yolk diameter. Dry matter \& protein of albumen and dry matter \& lipid of yolk were lower, while protein of yolk was higher in the morning eggs than those in the afternoon. It was observed that the storage period was important factor for egg quality characteristics. The effect of oviposition time and storage period interaction on egg quality should not be neglected. Interactions between cage type and storage period and between oviposition time and storage period were found statistically significant for some chemical composition of albumen and yolk. It is concluded that A quality egg criteria are preserved up to 14 days at an average temperature of $21^{\circ} \mathrm{C}$ and $20 \%$ humidity.
\end{abstract}

Keywords: Cage type, egg composition, egg quality, oviposition time, storage period.

\section{Yumurtacı tavuklarda kafes tipi, yumurtlama zamanı ve yumurta depolama süresinin yumurta kalite özelliklerine etkileri}

Özet: Yumurta değerli besinlere sahiptir, fakat bu besinler birçok faktörden etkilenebilir. Çalışmada, yumurtacı tavuklarda kafes tipi, yumurtlama zamanı ve depolama süresinin yumurta kalite özelliklerine etkilerini belirlemek amaçlanmıştır. Zenginleştirilmemiş ve zenginleştirilmiş kafeslerden sabah ve öğleden sonra toplam 410 yumurta toplanmıştır. Yumurtalar tartıldıktan sonra depolamanın 30. gününe kadar $21^{\circ} \mathrm{C}$ sıcaklık ve $\% 20$ nemde depolanmıştır. Zenginleştirilmemiş kafes yumurtaları, zenginleştirilmiş kafes yumurtaları ile karşılaştırıldığında daha yüksek kabuk kırılma mukavemeti, ak kül ve sarı pH \& yağ değerlerine ve daha düşük yumurta ağırlık kaybı, sarı indeksi \& sarı rengine sahip olduğu belirlenmiştir. Öğleden sonraki yumurtalara kıyasla sabah yumurtalarının daha yüksek yumurta ağırlık kaybı ile daha düşük yumurta ağırlığı, sarı yüksekliği ve sarı çapına sahip olduğu gözlenmiştir. Ayrıca bu yumurtalarda ak kuru madde \& protein düzeyi ile sarı kuru madde \& yağ düzeyi daha düşükken, sarı protein düzeyi daha yüksektir. Depolama süresinin yumurta kalite özellikleri için önemli bir faktör olduğu gözlenmiştir. Yumurtlama zamanı ve depolama süresi etkileşiminin yumurta kalitesi üzerindeki etkisi ihmal edilmemelidir. Kafes tipi ve depolama süresi ile yumurtlama zamanı ve depolama süresi arasındaki etkileşimler ak ve sarının bazı kimyasal bileşimleri için istatistik açıdan önemli bulunmuştur. A kalitede ki yumurtada aranan kriterlerin ortalama $21^{\circ} \mathrm{C}$ sıcaklıkta ve $\% 20$ nemde 14 güne kadar korunduğu sonucuna varılmıştır.

Anahtar sözcükler: Depolama süresi, kafes tipi, yumurta bileşimi, yumurta kalitesi, yumurtlama zamanı.

\section{Introduction}

The laying hen industry has moved away from unenriched cages (UEC) to housing systems that are considered more welfare-friendly systems such as enriched cages (EC). The increasing importance given to animal welfare has made consumers think that eggs obtained from alternative systems are healthier than those obtained from conventional systems. The alternative systems have focused on developing better animal welfare and behaviour for laying hens. These systems allow the birds to exhibit their natural behaviour, decrease the probability of disease \& injury, increase productivity, egg quality, and food safety $(11,16)$. 
Egg is a food containing most of the nutrients that human needs (26). Eggs are also an excellent source of protein and fat. Having the highest quality protein among animal products, they are also rich in vitamins such as A, $\mathrm{D}, \mathrm{E}, \mathrm{K}$ and $\mathrm{B}$, and minerals such as iron and phosphorus $(21,27)$. Egg quality is important for both producers and consumers. In terms of producers, it is desired that the egg is large, clean-looking, delicious, properly shaped, and has good shell quality and internal quality.

Egg processing guidelines and quality standards are based for UEC eggs. Egg quality characteristics are affected by many factors such as genotype of the hens, diet, environmental conditions and housing system used in production and oviposition time (3, 11, 12, 16, 17, 20). However, these effects may vary with the interaction between the factors examined. Egg has a limited shelf life depending on the storage conditions (2). However, the interactions of cage systems used in the production, oviposition time and storage conditions are not fully investigated. Therefore, the current study was aimed to determine the effects of cage type (UEC and EC), oviposition time, and egg storage period on egg quality characteristics of ISA-Brown laying hens aged 57 weeks.

\section{Materials and Methods}

The eggs were obtained from ISA-Brown laying hybrids aged 57 weeks that were kept in two caging systems (UEC and EC) in the same poultry house. Twenty hens were kept in the UEC system $(192 \mathrm{~cm}$ width, $62.5 \mathrm{~cm}$ depth, and $57 \mathrm{~cm}$ height), while 18 hens were kept in the EC system $(240 \mathrm{~cm}$ width, $62.5 \mathrm{~cm}$ depth and $57 \mathrm{~cm}$ height). EC included the nest $(48 \mathrm{~cm}$ width $\times 62.5 \mathrm{~cm}$ depth), scratch-pad (35 cm width $x 5 \mathrm{~cm}$ length), perch and claw shortener (12 $\mathrm{cm}$ width $\times 3 \mathrm{~cm}$ length). The nesting area was separated from the other areas with blue plastic strips. Two plastic perches were used with 190 and $137 \mathrm{~cm}$ in length. Each cage had eight nipple type drinkers. The lighting program was $16 \mathrm{~L}: 8 \mathrm{D}$ during the laying period. The average poultry house temperature on the day that the eggs were collected was $25.1^{\circ} \mathrm{C}$, and the average humidity was $31 \%$. The ingredients and the chemical composition of layer diet were given in Table 1. Chemical composition of the diet was determined according to the methods described by AOAC (4).

The eggs to be used in the study were collected from the poultry house for two consecutive days from 8:30 to 11:30 am, and from 13:30 to 16:30 (2 different oviposition times). Eggs with damaged shell structure were excluded from the study. A total of 410 eggs were selected for this study, 120 eggs in the morning and 90 eggs in the afternoon from UEC and 120 eggs in the morning and 80 eggs in the afternoon from the EC system.
Table 1. Ingredients and chemical composition of the diet.

\begin{tabular}{|c|c|}
\hline Ingredients, $\mathrm{g} / \mathrm{kg}$ as fed & Diet \\
\hline Maize & 520.24 \\
\hline Maize DDGS, $28 \%$ CP & 52.54 \\
\hline Wheat & 34.00 \\
\hline Full-fat soya & 154.08 \\
\hline Soybean meal,47\% CP & 9.22 \\
\hline Sunflower seed meal, $36 \% \mathrm{CP}$ & 118.33 \\
\hline Monocalcium phosphate & 5.49 \\
\hline Calcium carbonate & 93.50 \\
\hline Sodium bicarbonate & 1.21 \\
\hline Salt & 2.57 \\
\hline Methionine & 1.09 \\
\hline Lysine sulphate & 1.34 \\
\hline Choline chloride & 0.50 \\
\hline Vitamin premix ${ }^{\text {a }}$ & 1.00 \\
\hline Mineral premix ${ }^{b}$ & 1.00 \\
\hline Xylanase $^{c}$ & 0.38 \\
\hline Phytase $^{\mathrm{d}}$ & 0.50 \\
\hline Carophyll red & 2.44 \\
\hline Carophyll yellow & 0.57 \\
\hline \multicolumn{2}{|l|}{ Composition } \\
\hline Metabolizable energy ${ }^{\mathrm{e}}, \mathrm{MJ} / \mathrm{kg}$ & 11.67 \\
\hline Crude protein, $\%$ & 16.10 \\
\hline Ether extract, \% & 4.80 \\
\hline Crude fiber, $\%$ & 3.90 \\
\hline Crude ash, \% & 11.20 \\
\hline $\mathrm{Ca}, \%$ & 3.90 \\
\hline $\mathrm{P}, \%$ & 0.60 \\
\hline
\end{tabular}

a: Each kg contain 12000000 IU vitamin A, 5000000 IU vitamin D3, 65 g vitamin E, $3 \mathrm{~g}$ vitamin $\mathrm{K} 3,3 \mathrm{~g}$ vitamin B1, $7 \mathrm{~g}$ vitamin $\mathrm{B} 2,15 \mathrm{~g}$ calcium D-pantothenate, $4 \mathrm{~g}$ vitamin $\mathrm{B} 6,20 \mathrm{mg}$ vitamin B12, $60 \mathrm{~g}$ niacin, $2 \mathrm{~g}$ folic acid and $0.25 \mathrm{~g}$ biotin. ${ }^{\mathrm{b}}$ : Each $\mathrm{kg}$ contain $25 \mathrm{~g}$ iron, $16 \mathrm{~g}$ copper, $120 \mathrm{~g}$ manganese, $110 \mathrm{~g}$ zinc, $1.25 \mathrm{~g}$ iodine and $0.3 \mathrm{~g}$ selenium. c: Ronozyme ${ }^{\circledR} \mathrm{WX}$, $\mathrm{d}:$ Ronozyme ${ }^{\circledR}$ HiPhos, ${ }^{\text {e: }}$ Estimated using equation by Carpenter and Clegg (9).

After the eggs were weighed, they were stored at $21^{\circ} \mathrm{C}$ and $20 \%$ relative humidity until the last storage day. The quality characteristics of five eggs from each group were examined at the $1^{\text {st }}, 7^{\text {th }}, 14^{\text {th }}, 21^{\text {st }}$, and $30^{\text {th }}$ day of storage. In each storage period, egg weight, egg weight loss, shape index, shell breaking strength, shell weight, shell thickness, albumen height, albumen length, albumen width, albumen $\mathrm{pH}$, yolk color, yolk weight, yolk height, yolk diameter, yolk $\mathrm{pH}$, albumen index, yolk index, and the Haugh unit were determined $(27,28)$. Dry matter, total lipid, protein and ash values were determined (4) in the yolk and albumen samples.

Statistical analysis: Distribution, the homogeneity of variance of the data, was analyzed. Two-way ANOVA determined the effects of cage type and oviposition time on egg weight and shape index. The effects of cage type, oviposition time and storage period to all the other 
examined properties were determined by using three-way ANOVA with SPSS for Windows (SPSS Inc., Chicago, IL). Tukey test was used to check the significance of the difference between the groups. $\mathrm{P} \leq 0.05$ was taken into account statistically significant (10).

\section{Results}

The effects of cage type and oviposition time on egg weight and shape index were given in the Table 2. It was observed that the weight of the eggs collected between 08.30 and 11.30 was lower than those were collected between 13.30 and $16.30(\mathrm{P}<0.001)$. In this study, it was determined that the shape index was not affected by cage type and oviposition time. No interaction was observed between the cage type and the oviposition time in terms of egg weight and shape index.

The egg weight loss during the storage period (Table 3) was higher in eggs obtained from EC than in UEC $(\mathrm{P}<0.001)$. The weight loss in eggs stored at room temperature increased from 0.13 to $4.15 \mathrm{~g}$ and percentage of weight loss increased from 0.20 to $6.39 \%$ as storage length increased. For egg weight loss, the interaction between cage type and storage period \& oviposition time and storage period were found to be statistically significant. Greater weight losses were obtained in the eggs from EC in the $14^{\text {th }}$ and $21^{\text {st }}$ days of storage and also

Table 2. Effects of cage type and oviposition time on egg weight and shape index of eggs.

\begin{tabular}{|c|c|c|c|c|}
\hline Cage type & Oviposition time & $\mathbf{n}$ & $\begin{array}{l}\text { Egg weight } \\
\text { (g) }\end{array}$ & Shape index (\%) \\
\hline UEC & & 210 & $65.29 \pm 0.32$ & $80.09 \pm 0.18$ \\
\hline \multirow[t]{3}{*}{$\mathrm{EC}$} & & 200 & $66.11 \pm 0.33$ & $79.93 \pm 0.18$ \\
\hline & $08.30-11.30$ & 240 & $64.81 \pm 0.30$ & $80.11 \pm 0.16$ \\
\hline & $13.30-16.30$ & 170 & $66.60 \pm 0.35$ & $79.91 \pm 0.19$ \\
\hline \multirow[t]{2}{*}{ UEC } & $08.30-11.30$ & 120 & $64.38 \pm 0.42$ & $80.16 \pm 0.23$ \\
\hline & $13.30-16.30$ & 90 & $66.21 \pm 0.49$ & $80.01 \pm 0.26$ \\
\hline \multirow[t]{3}{*}{$\mathrm{EC}$} & $08.30-11.30$ & 120 & $65.24 \pm 0.42$ & $80.05 \pm 0.23$ \\
\hline & $13.30-16.30$ & 80 & $66.99 \pm 0.51$ & $79.81 \pm 0.28$ \\
\hline & & & $\mathrm{P}$ & \\
\hline Cage type & & & 0.078 & 0.531 \\
\hline Oviposition time & & & $<0.001$ & 0.432 \\
\hline Cage type X Oviposition time & & & 0.930 & 0.861 \\
\hline
\end{tabular}

UEC: unenriched cages, EC: enriched cages, Mean \pm SEM.

Table 3. Effects of cage type, oviposition time and storage period on egg weight loss and shell quality of eggs.

\begin{tabular}{|c|c|c|c|c|c|c|c|}
\hline $\begin{array}{l}\text { Cage } \\
\text { type }\end{array}$ & $\begin{array}{c}\text { Oviposition } \\
\text { time }\end{array}$ & $\begin{array}{l}\text { Storage period } \\
\text { (day) }\end{array}$ & $\begin{array}{l}\text { Weight loss } \\
\text { (g) }\end{array}$ & $\begin{array}{l}\text { Weight loss } \\
(\%)\end{array}$ & $\begin{array}{c}\text { Breaking strength } \\
\left(\mathrm{kg} / \mathrm{cm}^{2}\right)\end{array}$ & $\begin{array}{l}\text { Shell thickness } \\
(\mathrm{mm})\end{array}$ & $\begin{array}{c}\text { Shell weight } \\
(\%)\end{array}$ \\
\hline UEC & & & $1.87 \pm 0.04$ & $2.90 \pm 0.05$ & $3.63 \pm 0.04$ & $38.37 \pm 0.14$ & $11.80 \pm 0.06$ \\
\hline \multirow[t]{9}{*}{$\mathrm{EC}$} & & & $2.05 \pm 0.04$ & $3.10 \pm 0.05$ & $3.50 \pm 0.05$ & $38.24 \pm 0.15$ & $11.65 \pm 0.06$ \\
\hline & $08.30-11.30$ & & $1.97 \pm 0.03$ & $3.07 \pm 0.05$ & $3.57 \pm 0.04$ & $38.13 \pm 0.13$ & $11.80 \pm 0.05$ \\
\hline & $13.30-16.30$ & & $1.94 \pm 0.04$ & $2.92 \pm 0.06$ & $3.57 \pm 0.05$ & $38.47 \pm 0.16$ & $11.65 \pm 0.06$ \\
\hline & & 1 & $0.13 \pm 0.06^{\mathrm{a}}$ & $0.20 \pm 0.08^{\mathrm{a}}$ & $3.16 \pm 0.07^{\mathrm{a}}$ & $37.91 \pm 0.23$ & $11.46 \pm 0.09^{\mathrm{a}}$ \\
\hline & & 7 & $0.91 \pm 0.06^{\mathrm{b}}$ & $1.39 \pm 0.08^{\mathrm{b}}$ & $3.12 \pm 0.07^{\mathrm{a}}$ & $38.58 \pm 0.23$ & $11.61 \pm 0.09^{\mathrm{ab}}$ \\
\hline & & 14 & $1.73 \pm 0.06^{\mathrm{c}}$ & $2.64 \pm 0.08^{\mathrm{c}}$ & $3.39 \pm 0.07^{\mathrm{a}}$ & $38.15 \pm 0.23$ & $11.58 \pm 0.09^{\mathrm{ab}}$ \\
\hline & & 21 & $2.86 \pm 0.06^{\mathrm{d}}$ & $4.37 \pm 0.08^{\mathrm{d}}$ & $3.36 \pm 0.07^{\mathrm{a}}$ & $38.44 \pm 0.24$ & $11.92 \pm 0.09^{\mathrm{ab}}$ \\
\hline & & 30 & $4.15 \pm 0.06^{\mathrm{e}}$ & $6.39 \pm 0.08^{\mathrm{e}}$ & $4.81 \pm 0.07^{b}$ & $38.45 \pm 0.22$ & $12.05 \pm 0.09^{b}$ \\
\hline & & & & $\mathrm{P}$ & & & \\
\hline \multicolumn{3}{|c|}{ Cage type } & $<0.001$ & 0.006 & 0.035 & 0.550 & 0.068 \\
\hline \multicolumn{3}{|c|}{ Oviposition time } & 0.595 & 0.038 & 0.964 & 0.098 & 0.064 \\
\hline \multicolumn{3}{|c|}{ Storage period } & $<0.001$ & 0.000 & $<0.001$ & 0.235 & $<0.001$ \\
\hline \multicolumn{3}{|c|}{ Cage type X Oviposition time } & 0.356 & 0.228 & 0.156 & 0.180 & 0.092 \\
\hline \multicolumn{3}{|c|}{ Cage type X Storage period } & 0.009 & 0.065 & 0.876 & 0.632 & 0.091 \\
\hline \multicolumn{3}{|c|}{ Oviposition time X Storage period } & $<0.001$ & 0.027 & 0.048 & 0.336 & 0.272 \\
\hline \multicolumn{3}{|c|}{$\begin{array}{l}\text { Cage type X Oviposition time X Storage } \\
\text { period }\end{array}$} & 0.774 & 0.351 & 0.203 & 0.833 & 0.878 \\
\hline
\end{tabular}

UEC: unenriched cages, EC: enriched cages, Mean \pm SEM, ${ }^{\text {a, b, } c, d, e: \text { The difference among means carrying different letters in the same }}$ column is statistically significant $(\mathrm{P}<0.05)$. 
in the eggs laid in the afternoon in the last week of storage. In the study, the breaking strength of eggs obtained from UEC was higher than those obtained from EC $(\mathrm{P}<0.05)$. Breaking strength of eggs increased from 3.16 to 4.81 $\mathrm{kg} / \mathrm{cm}^{2}$ and shell weight increased from 11.46 to $12.05 \%$ as length of storage period increased. According to the findings obtained from the study, the effects of oviposition time on breaking strength, shell thickness, and shell percentage were found to be statistically insignificant.

The effects of the cage type, oviposition time and storage period on albumen quality and Haugh unit were given in the Table 4 . Only storage period affected the examined traits $(\mathrm{P}<0.001)$. The interaction between oviposition time and storage period on the percentage and $\mathrm{pH}$ of the albumen and Haugh unit were statistically significant $(\mathrm{P}<0.05)$.

No significant effects of the cage type on the percentage, height, and diameter of the yolk were observed (Table 5). The eggs obtained from EC had higher yolk index and darker yolk color and had lower yolk $\mathrm{pH}$ than those obtained from UEC $(\mathrm{P} \leq 0.05)$. There was no difference in groups of cage type and oviposition time in terms of yolk percentage. The height and diameter of yolk were lower in eggs in the morning than those in the afternoon $(\mathrm{P}<0.01)$. There were no significant effects of oviposition time on index, color, and $\mathrm{pH}$ of the yolk. The yolk percentage increased in eggs stored at room temperature for 30 days $(\mathrm{P}<0.001)$. While yolk diameter increased, yolk height and consequently, yolk index decreased $(\mathrm{P}<0.001)$. The reduction in yolk index was greater in the eggs laid in the morning than those in the afternoon as the storage period increased. The yolk $\mathrm{pH}$ increased in eggs stored at room temperature for 30 days $(\mathrm{P}<0.001)$. While the yolk color decreased in the first seven days of the storage period, it started to increase again after the $7^{\text {th }}$ day $(\mathrm{P}<0.001)$. The interaction between oviposition time and storage period had an important effect on all the properties of yolk quality $(\mathrm{P}<0.01)$. The interaction between the cage type and the storage period was effective in $\mathrm{pH}$ and diameter of yolk $(\mathrm{P}<0.05)$. The interaction between cage type, oviposition time, and storage period was observed to be effective in $\mathrm{pH}$, height, diameter, color, and index of yolk $(\mathrm{P}<0.01)$. The effects of cage type, oviposition time and storage period on chemical composition were given in the Table 6. Ash of albumen and dry matter of yolk were found as 0.75 and $46.83 \%$ \& 0.71 and $46.25 \%$ in UEC and EC eggs, respectively $(\mathrm{P}<0.001)$. Oviposition time was found important for dry matter and protein of albumen $\&$ dry matter protein and lipid of yolk values. Storage period and interaction of oviposition time \& storage period affected the composition of albumen and yolk $(\mathrm{P}<0.001)$.

Table 4. Effects of cage type, oviposition time and storage period on albumen quality and Haugh unit of eggs.

\begin{tabular}{|c|c|c|c|c|c|c|c|c|c|}
\hline $\begin{array}{l}\text { Cage } \\
\text { type }\end{array}$ & $\begin{array}{c}\text { Oviposition } \\
\text { time }\end{array}$ & $\begin{array}{c}\text { Storage } \\
\text { period } \\
\text { (day) }\end{array}$ & $\begin{array}{c}\text { Albumen } \\
\text { percentage } \\
(\%)\end{array}$ & $\begin{array}{c}\text { Albumen } \\
\text { pH }\end{array}$ & $\begin{array}{c}\text { Albumen } \\
\text { height } \\
(\mathbf{m m})\end{array}$ & $\begin{array}{c}\text { Albumen } \\
\text { length } \\
(\mathbf{m m})\end{array}$ & $\begin{array}{c}\text { Albumen } \\
\text { width } \\
(\mathbf{m m})\end{array}$ & $\begin{array}{l}\text { Albumen } \\
\text { index }\end{array}$ & Haugh unit \\
\hline UEC & & & $61.33 \pm 0.17$ & $9.15 \pm 0.02$ & $4.36 \pm 0.03$ & $107.94 \pm 0.72$ & $87.89 \pm 0.70$ & $4.78 \pm 0.06$ & $54.91 \pm 0.43$ \\
\hline \multirow[t]{8}{*}{$\mathrm{EC}$} & & & $61.28 \pm 0.17$ & $9.16 \pm 0.02$ & $4.30 \pm 0.04$ & $109.54 \pm 0.76$ & $88.70 \pm 0.73$ & $4.67 \pm 0.06$ & $54.26 \pm 0.44$ \\
\hline & $08.30-11.30$ & & $61.35 \pm 0.15$ & $9.17 \pm 0.02$ & $4.30 \pm 0.03$ & $108.49 \pm 0.67$ & $87.45 \pm 0.65$ & $4.73 \pm 0.05$ & $54.66 \pm 0.39$ \\
\hline & $13.30-16.30$ & & $61.27 \pm 0.18$ & $9.14 \pm 0.02$ & $4.36 \pm 0.04$ & $108.98 \pm 0.80$ & $89.14 \pm 0.77$ & $4.72 \pm 0.06$ & $54.50 \pm 0.47$ \\
\hline & & 1 & $63.47 \pm 0.25^{\mathrm{d}}$ & $8.66 \pm 0.03^{\mathrm{a}}$ & $7.13 \pm 0.05^{\mathrm{d}}$ & $90.65 \pm 0.97^{\mathrm{a}}$ & $73.29 \pm 0.94^{\mathrm{a}}$ & $8.73 \pm 0.08^{\mathrm{d}}$ & $82.17 \pm 0.61^{\mathrm{d}}$ \\
\hline & & 7 & $62.78 \pm 0.25^{\mathrm{c}}$ & $9.13 \pm 0.03^{\mathrm{b}}$ & $4.78 \pm 0.05^{\mathrm{c}}$ & $107.85 \pm 1.00^{\mathrm{b}}$ & $84.40 \pm 0.96^{b}$ & $5.03 \pm 0.08^{c}$ & $64.11 \pm 0.62^{\mathrm{c}}$ \\
\hline & & 14 & $61.44 \pm 0.25^{\mathrm{b}}$ & $9.22 \pm 0.03^{\mathrm{b}}$ & $3.40 \pm 0.05^{\mathrm{b}}$ & $115.14 \pm 1.16^{\mathrm{c}}$ & $92.38 \pm 1.12^{\mathrm{c}}$ & $3.34 \pm 0.09^{\mathrm{b}}$ & $48.10 \pm 0.62^{b}$ \\
\hline & & 21 & $59.86 \pm 0.28^{\mathrm{a}}$ & $9.33 \pm 0.03^{\mathrm{c}}$ & $2.02 \pm 0.05^{\mathrm{a}}$ & $121.30 \pm 1.05^{\mathrm{d}}$ & $103.10 \pm 1.01^{\mathrm{d}}$ & $1.80 \pm 0.08^{\mathrm{a}}$ & $23.94 \pm 0.61^{\mathrm{a}}$ \\
\hline & & 30 & $58.98 \pm 0.28^{\mathrm{a}}$ & $9.43 \pm 0.03^{\mathrm{c}}$ & - & - & - & - & - \\
\hline \multicolumn{10}{|l|}{$\mathrm{P}$} \\
\hline \multicolumn{3}{|c|}{ Cage type } & 0.837 & 0.632 & 0.244 & 0.126 & 0.421 & 0.170 & 0.290 \\
\hline \multicolumn{3}{|c|}{ Oviposition time } & 0.736 & 0.320 & 0.213 & 0.643 & 0.096 & 0.929 & 0.791 \\
\hline \multicolumn{3}{|c|}{ Storage period } & $<0.001$ & $<0.001$ & $<0.001$ & $<0.001$ & $<0.001$ & $<0.001$ & $<0.001$ \\
\hline \multicolumn{3}{|c|}{ Cage type X Oviposition time } & 0.878 & 0.771 & 0.090 & 0.002 & 0.269 & 0.672 & 0.193 \\
\hline \multicolumn{3}{|c|}{ Cage type X Storage period } & 0.358 & 0.807 & 0.907 & 0.323 & 0.475 & 0.833 & 0.892 \\
\hline \multicolumn{3}{|c|}{$\begin{array}{l}\text { Oviposition time X Storage } \\
\text { period }\end{array}$} & 0.004 & 0.038 & 0.083 & 0.305 & 0.231 & 0.203 & 0.034 \\
\hline \multicolumn{3}{|c|}{$\begin{array}{l}\text { Cage type X Oviposition time } \\
\text { X Storage period }\end{array}$} & 0.539 & 0.661 & 0.739 & 0.204 & 0.272 & 0.648 & 0.291 \\
\hline
\end{tabular}

UEC: unenriched cages, EC: enriched cages, Mean \pm SEM, a, b, c, d: The difference among means carrying different letters in the same column is statistically significant $(\mathrm{P}<0.05)$. 
Table 5. Effects of cage type, oviposition time and storage period on yolk quality of eggs.

\begin{tabular}{|c|c|c|c|c|c|c|c|c|}
\hline $\begin{array}{l}\text { Cage } \\
\text { type }\end{array}$ & $\begin{array}{l}\text { Oviposition } \\
\text { time }\end{array}$ & $\begin{array}{l}\text { Storage } \\
\text { period } \\
\text { (day) }\end{array}$ & $\begin{array}{c}\text { Yolk } \\
\text { percentage } \\
(\%)\end{array}$ & Yolk pH & $\begin{array}{l}\text { Yolk height } \\
\text { (mm) }\end{array}$ & $\begin{array}{l}\text { Yolk diameter } \\
(\mathrm{mm})\end{array}$ & Yolk index & Yolk color \\
\hline UEC & & & $26.89 \pm 0.15$ & $6.09 \pm 0.01$ & $13.58 \pm 0.06$ & $43.04 \pm 0.14$ & $31.86 \pm 0.18$ & $9.97 \pm 0.04$ \\
\hline \multirow[t]{9}{*}{$\mathrm{EC}$} & & & $27.10 \pm 0.15$ & $6.06 \pm 0.01$ & $13.74 \pm 0.06$ & $42.69 \pm 0.14$ & $32.56 \pm 0.18$ & $10.08 \pm 0.04$ \\
\hline & $08.30-11.30$ & & $26.87 \pm 0.13$ & $6.07 \pm 0.01$ & $13.49 \pm 0.06$ & $42.59 \pm 0.12$ & $32.02 \pm 0.16$ & $10.02 \pm 0.04$ \\
\hline & $13.30-16.30$ & & $27.12 \pm 0.17$ & $6.07 \pm 0.01$ & $13.83 \pm 0.07$ & $43.14 \pm 0.15$ & $32.40 \pm 0.20$ & $10.03 \pm 0.05$ \\
\hline & & 1 & $25.08 \pm 0.22^{\mathrm{a}}$ & $5.93 \pm 0.02^{\mathrm{a}}$ & $15.63 \pm 0.10^{\mathrm{d}}$ & $40.22 \pm 0.20^{\mathrm{a}}$ & $38.90 \pm 0.27^{\mathrm{e}}$ & $10.28 \pm 0.06^{\mathrm{c}}$ \\
\hline & & 7 & $25.64 \pm 0.23^{\mathrm{a}}$ & $5.94 \pm 0.02^{\mathrm{a}}$ & $14.65 \pm 0.10^{\mathrm{c}}$ & $40.47 \pm 0.21^{\mathrm{a}}$ & $36.24 \pm 0.27^{\mathrm{d}}$ & $9.74 \pm 0.06^{\mathrm{a}}$ \\
\hline & & 14 & $27.00 \pm 0.23^{\mathrm{b}}$ & $6.00 \pm 0.02^{\mathrm{b}}$ & $14.30 \pm 0.10^{\mathrm{b}}$ & $42.50 \pm 0.21^{\mathrm{b}}$ & $33.68 \pm 0.28^{\mathrm{c}}$ & $9.83 \pm 0.06^{\mathrm{ab}}$ \\
\hline & & 21 & $28.29 \pm 0.26^{\mathrm{c}}$ & $6.09 \pm 0.02^{\mathrm{c}}$ & $11.72 \pm 0.11^{\mathrm{a}}$ & $44.45 \pm 0.23^{\mathrm{c}}$ & $26.43 \pm 0.30^{\mathrm{b}}$ & $10.02 \pm 0.07^{b}$ \\
\hline & & 30 & $28.98 \pm 0.25^{\mathrm{d}}$ & $6.39 \pm 0.02^{\mathrm{d}}$ & $11.99 \pm 0.11^{\mathrm{a}}$ & $46.69 \pm 0.23^{\mathrm{d}}$ & $25.79 \pm 0.30^{\mathrm{a}}$ & $10.27 \pm 0.07^{\mathrm{c}}$ \\
\hline & & & & $\mathrm{P}$ & & & & \\
\hline \multicolumn{3}{|c|}{ Cage type } & 0.315 & 0.027 & 0.070 & 0.068 & 0.006 & 0.050 \\
\hline \multicolumn{3}{|c|}{ Oviposition time } & 0.233 & 0.729 & $<0.001$ & 0.005 & 0.132 & 0.814 \\
\hline \multicolumn{3}{|c|}{ Storage period } & $<0.001$ & $<0.001$ & $<0.001$ & $<0.001$ & $<0.001$ & $<0.001$ \\
\hline \multicolumn{3}{|c|}{ Cage type X Oviposition time } & 0.575 & 0.955 & 0.358 & 0.284 & 0.698 & 0.744 \\
\hline \multicolumn{3}{|c|}{ Cage type X Storage period } & 0.482 & 0.039 & 0.082 & 0.010 & 0.195 & 0.283 \\
\hline \multicolumn{3}{|c|}{ Oviposition time X Storage period } & 0.003 & $<0.001$ & $<0.001$ & $<0.001$ & 0.003 & $<0.001$ \\
\hline \multicolumn{3}{|c|}{$\begin{array}{l}\text { Cage type X Oviposition time X } \\
\text { Storage period }\end{array}$} & 0.355 & 0.004 & 0.002 & 0.003 & 0.001 & 0.896 \\
\hline
\end{tabular}

Table 6. Effects of cage type, oviposition time and storage period on chemical composition of eggs.

\begin{tabular}{|c|c|c|c|c|c|c|c|c|c|}
\hline \multirow{2}{*}{$\begin{array}{l}\text { Cage } \\
\text { type }\end{array}$} & \multirow{2}{*}{$\begin{array}{c}\text { Oviposition } \\
\text { time }\end{array}$} & \multirow{2}{*}{$\begin{array}{c}\text { Storage } \\
\text { period } \\
\text { (day) }\end{array}$} & \multicolumn{3}{|c|}{ Albumen } & \multicolumn{4}{|c|}{ Yolk } \\
\hline & & & $\begin{array}{c}\text { Dry matter } \\
(\%)\end{array}$ & $\begin{array}{l}\text { Ash } \\
(\%)\end{array}$ & $\begin{array}{l}\text { Protein } \\
(\%)\end{array}$ & $\begin{array}{c}\text { Dry matter } \\
(\%)\end{array}$ & $\begin{array}{l}\text { Ash } \\
(\%)\end{array}$ & $\begin{array}{l}\text { Protein } \\
(\%)\end{array}$ & $\begin{array}{l}\text { Lipid } \\
\text { (\%) }\end{array}$ \\
\hline \multicolumn{3}{|l|}{ UEC } & $11.65 \pm 0.07$ & $0.75 \pm 0.01$ & $10.86 \pm 0.07$ & $46.83 \pm 0.09$ & $1.57 \pm 0.02$ & $15.40 \pm 0.04$ & $29.86 \pm 0.08$ \\
\hline \multirow[t]{9}{*}{$\mathrm{EC}$} & & & $11.57 \pm 0.07$ & $0.71 \pm 0.01$ & $10.81 \pm 0.07$ & $46.25 \pm 0.09$ & $1.57 \pm 0.02$ & $15.49 \pm 0.04$ & $29.16 \pm 0.08$ \\
\hline & \multicolumn{2}{|l|}{$08.30-11.30$} & $11.41 \pm 0.07$ & $0.73 \pm 0.01$ & $10.63 \pm 0.07$ & $46.36 \pm 0.09$ & $1.55 \pm 0.02$ & $15.51 \pm 0.04$ & $29.29 \pm 0.08$ \\
\hline & \multicolumn{2}{|l|}{$13.30-16.30$} & $11.81 \pm 0.07$ & $0.74 \pm 0.01$ & $11.04 \pm 0.07$ & $46.72 \pm 0.09$ & $1.59 \pm 0.02$ & $15.38 \pm 0.04$ & $29.73 \pm 0.08$ \\
\hline & & 1 & $11.13 \pm 0.11^{\mathrm{a}}$ & $0.72 \pm 0.01^{\mathrm{a}}$ & $10.35 \pm 0.11^{\mathrm{a}}$ & $48.48 \pm 0.15^{\mathrm{d}}$ & $1.70 \pm 0.03^{b}$ & $15.69 \pm 0.06^{\mathrm{c}}$ & $31.70 \pm 0.12^{\mathrm{d}}$ \\
\hline & & 7 & $11.11 \pm 0.11^{\mathrm{a}}$ & $0.69 \pm 0.01^{\mathrm{a}}$ & $10.38 \pm 0.11^{\mathrm{a}}$ & $47.19 \pm 0.15^{\mathrm{c}}$ & $1.68 \pm 0.03^{b}$ & $15.47 \pm 0.06^{\mathrm{bc}}$ & $30.02 \pm 0.12^{\mathrm{c}}$ \\
\hline & & 14 & $11.69 \pm 0.11^{\mathrm{b}}$ & $0.71 \pm 0.01^{\mathrm{a}}$ & $10.94 \pm 0.11^{\mathrm{b}}$ & $46.35 \pm 0.15^{\mathrm{c}}$ & $1.52 \pm 0.03^{\mathrm{a}}$ & $15.42 \pm 0.06^{\mathrm{bc}}$ & $29.39 \pm 0.12^{b}$ \\
\hline & & 21 & $11.93 \pm 0.11^{\mathrm{bc}}$ & $0.77 \pm 0.01^{\mathrm{b}}$ & $11.13 \pm 0.11^{\mathrm{bc}}$ & $46.05 \pm 0.15^{\mathrm{b}}$ & $1.52 \pm 0.03^{\mathrm{a}}$ & $15.45 \pm 0.06^{\mathrm{bc}}$ & $29.06 \pm 0.12^{\mathrm{b}}$ \\
\hline & & 30 & $12.20 \pm 0.11^{\mathrm{c}}$ & $0.77 \pm 0.01^{\mathrm{b}}$ & $11.34 \pm 0.11^{\mathrm{c}}$ & $44.63 \pm 0.15^{\mathrm{a}}$ & $1.44 \pm 0.03^{\mathrm{a}}$ & $15.20 \pm 0.06^{\mathrm{a}}$ & $28.00 \pm 0.12^{\mathrm{a}}$ \\
\hline & & & & & $\mathrm{P}$ & & & & \\
\hline \multicolumn{3}{|c|}{ Cage type } & 0.424 & $<0.001$ & 0.660 & $<0.001$ & 0.947 & 0.081 & $<0.001$ \\
\hline \multicolumn{3}{|c|}{ Oviposition time } & $<0.001$ & 0.534 & $<0.001$ & 0.007 & 0.227 & 0.015 & $<0.001$ \\
\hline \multicolumn{3}{|c|}{ Storage period } & $<0.001$ & $<0.001$ & $<0.001$ & $<0.001$ & $<0.001$ & $<0.001$ & $<0.001$ \\
\hline \multicolumn{3}{|c|}{ Cage type X Oviposition time } & 0.172 & 0.925 & 0.187 & 0.264 & 0.636 & 0.064 & 0.016 \\
\hline \multicolumn{3}{|c|}{ Cage type X Storage period } & 0.010 & 0.008 & 0.020 & 0.017 & 0.098 & 0.154 & $<0.001$ \\
\hline \multicolumn{3}{|c|}{$\begin{array}{l}\text { Oviposition time X Storage } \\
\text { period }\end{array}$} & $<0.001$ & 0.232 & $<0.001$ & 0.024 & 0.052 & 0.002 & 0.001 \\
\hline \multicolumn{3}{|c|}{$\begin{array}{l}\text { Cage type X Oviposition time X } \\
\text { Storage period }\end{array}$} & 0.226 & 0.209 & 0.255 & 0.183 & 0.841 & 0.600 & 0.093 \\
\hline
\end{tabular}




\section{Discussion and Conclusion}

There were no significant effects of the cage type on egg weight. The results are in agreement with studies (18, 20) about the effect of the housing system on laying hens. However, Dikmen et al. (11) reported that egg weight was higher in eggs obtained from UEC than those obtained from EC. This may be due to the genotype and age of the laying hens, stocking density and differentiation of the enrichment materials.

In the poultry house where the study was conducted, ovulation in the morning eggs occurred three hours after the dark period, while in the afternoon, ovulation took place six hours after the dark period. The maturation of the yolk and the albumen accumulation in the eggs laid in the afternoon coincides with the period when the laying hens were active, and it may cause to increase egg weight. Some researchers $(1,7,17,23,24)$ stated that eggs laid in the morning were heavier than those in the afternoon. However, Ayorinde and Olagbuyiro (5) and Tumová et al. (25) reported that oviposition time did not affect the egg weight. The difference in the studies about the effects of oviposition time on egg weight is thought to be due to the lighting program applied in the poultry house, namely the starting hours of the light and dark period. This situation can be influenced by the time of albumen formation in the oviduct coincides with the light period.

Batkowska et al. (6) described that the weight loss in eggs was higher in eggs obtained from UEC than those from EC. However, in our study, high egg weight loss was seen in EC eggs. The difference in the studies is due to the age of the laying hens. The shell quality of the eggs deteriorated with increasing hen age. The interaction between the age of the hens and the cage type may have occurred. Weight loss percentage was higher in eggs collected in the morning than those in the afternoon. This may be explained that the eggs laid in the morning had less light period during the formation of the eggshell and the lower $\mathrm{Ca}$ level had in the blood of the hens compared to the afternoon eggs. High egg weight losses were seen in the EC eggs during the egg storage periods. This may be due to the lower shell breaking strength in these eggs. The interaction between oviposition time and storage period was found to be statistically significant, as eggs laid in the afternoon had more weight loss during the last week of storage than those in the morning.

In the present study, the breaking strength in the UEC eggs was higher than those of EC eggs. This may be due to the increase in carbondioxide loss because of the high activity of hens in EC and the inability of calcium carbonate formation by decreasing the blood's calcium binding ability. The effect of the cage type on the shell thickness was found statistically insignificant. Tumová et al. (25) and Onbaşılar and Avcılar (17) found that shell breaking strength, shell thickness, and shell percentage in eggs laid in the afternoon were better than those in the morning. The shell formation covers approximately 20-21 hours. Calcium need for the shell formation is especially important in the dark period because there is no feed consumption in this period. In the present study, the percentage of shell increased as a result of increasing the length of storage period. This can be explained by the increase in the shell rate as a result of the evaporation of the water in the albumen and yolk over time. Breaking strength increased in eggs stored at room temperature for 30 days. The reason for this may be shell contains $0.1 \%$ water, and water decreases over time with increasing storage period. The effect of interaction between oviposition time and storage period on shell breaking strength was found statistically significant. This was due to the higher breaking strength of eggs laid in the afternoon on the $14^{\text {th }}$ day of storage than those in the morning.

There were no significant effects of the cage type and oviposition time on percentage, height, length, width, $\mathrm{pH}$, and index of the albumen and Haugh unit. Results of some researches $(7,23,25)$ consistent with the study. Similarly, Karkulín (15) reported that the cage type was not effective on the albumen height and Haugh unit. The percentage of albumen was decreased in eggs stored at room temperature for 30 days. Depending on the age of the hens, water constitutes about $87-89 \%$ of an albumen and the decrease in the percentage of albumen may be due to the high amount of water loss. While the length and width of albumen increased, height and index of albumen decreased in eggs stored at room temperature for 21 days. The decrease in albumen height is caused by the breakdown of ovomucin (22). In table eggs, AA quality egg should be 79 or higher, A quality 55-78, B quality 3154 , and C quality 30 or less. In our study, after 21 days of storage, the Haugh unit decreased from 82.17 to $23.94 \%$. The decrease in the Haugh unit may be due to the decrease in albumen height because of the destruction of ovomucin and lysozyme complex. It was observed that the reduction in the Haugh unit increased in the afternoon eggs as the storage period increased. The $\mathrm{pH}$ of the albumen is reported between 7.6 and 8.5 (30). The increase in the albumen $\mathrm{pH}$ was higher in the first week of storage compared to other weeks. Immediately after ovulation, the egg starts to lose carbon dioxide from the pores of the shell, and the albumen $\mathrm{pH}$ rises (14). The increase in albumen $\mathrm{pH}$ level mainly depends on the temperature and duration of storage and the egg shell quality (25).

The increase in the percentage of the yolk with storage period may be due to the passage of water from the albumen to the yolk (2). The increase in yolk pH with storage period is due to the loss of carbon dioxide from the 
egg. Stress factors in relation to the production system alter blood protein and lipid levels of hens (29). The chemical content of egg is related to the blood chemistry of hen. Albumen ash and dry matter \&lipid of yolk were found lower in eggs obtained from the EC than those from the UEC. Dry matter \& protein of albumen and dry matter $\&$ lipid of yolk were higher, while protein of yolk was lower in the afternoon egg than those in the morning. Dry matter, ash and protein of albumen were increased, while dry matter, ash, protein and lipid of yolk were decreased with increasing storage period at the room temperature. The dry matter concentration of albumen is also used as an indicator of egg freshness and is related to thinning or liquefaction of albumen (13). Caner and Yüceer (8) reported that dry matter of albumen increases with storage period as a result of albumen liquefaction. Interaction of cage type and oviposition time on yolk lipid, interaction of cage type and storage period on all examined albumen composition and dry matter \& lipid of yolk and interaction of oviposition time and storage period on dry matter \& protein of albumen and dry matter, protein $\&$ lipid of yolk were found statistically significant in the present study.

In conclusion, cage type (UEC or EC) had no significant effect on egg quality during storage conditions except weight loss, breaking strength, ash of albumen and $\mathrm{pH}$, index, color, dry matter \& lipid of yolk. Yolk protein was higher, while albumen protein and yolk lipid were lower in the morning eggs than those in the afternoon. No interaction was observed between the cage type and the oviposition time in terms of the examined properties except that albumen length and yolk lipid. However, the interaction between oviposition time and storage period should not be neglected in the egg quality. It should be noted that interaction among cage type, oviposition time, and storage period is also effective in some yolk properties. It is concluded that A quality egg criteria are preserved up to 14 days at an average temperature of $21^{\circ} \mathrm{C}$ and $20 \%$ humidity.

\section{Acknowledgements}

Some part of this article was summarized from the first author's master thesis.

\section{Financial Support}

This research received no grant from any funding agency/sector.

\section{Ethical Statement}

This study does not present any ethical concerns.

\section{Conflict of Interest}

The authors are declared that there is no conflict of interest.

\section{References}

1. Aksoy T, Yilmaz M, Tuna T (2001): The effect of oviposition time on egg quality and the possibility of estimating egg shell weight using a formula in commercial layers. Turk J Vet Anım Sci, 25, 811-816.

2. Akyurek H, Okur AA (2009): Effect of storage time, temperature and hen age on egg quality in free-range layer hens. J Anım Vet Adv, 8, 1953-1958.

3. Angelovičová M, Ševčíková V, Angelovič M, et al (2014): Comparison of two different breeding systems laying hens in relation to egg shell quality. J Anim Sci Biotechno, 47, 166-171.

4. AOAC (2000): Official Methods of Analysis. 17th ed. AOAC International, Maryland, USA.

5. Ayorinde KL, Olagbuyiro B (1991): The influence of clutch size and oviposition time on egg weight and egg index in Hubbard layers. Bull Anim Health Prod Afr, 39, 251253.

6. Batkowska J, Brodacki A, Knaga S (2014): Quality of laying hen eggs during storage depending on egg weight and type of cage system (conventional vs. furnished cages). Ann Anim Sci, 14, 707-719.

7. Campo J, Cigarroa F, Torres O (2015): Effect of oviposition time on egg quality characteristics. World's Poult Sci J, 71, 106.

8. Caner C, Yüceer M (2015): Efficacy of various proteinbased coating on enhancing the shelf life of fresh eggs during storage. Poult Sci, 94, 1665-1677.

9. Carpenter K, Clegg K (1956): The metabolizable energy of poultry feeding stuffs in relation to their chemical composition. J Sci Food Agri, 7, 45-51.

10. Dawson B, Trapp RG (2001): Basic and Clinical Biostatistics, 3rd ed. Lange Medical Books. McGraw-Hill Medical Publishing Division, New York.

11. Dikmen BY, Ipek A, Şahan Ü et al (2017): Impact of different housing systems and age of layers on egg quality characteristics. Turk J Vet Anım Sci, 41, 77-84.

12. Hanusova E, Hrnčár C, Hanus A, et al (2015): Effect of breed on some parameters of egg quality in laying hens. Acta Fytotechn Zootechn, 18, 20-24.

13. Heldman DR (2011): Food preservation process design. Procedia Food Sci, 1, 685-689.

14. Hill AT, Hall JW (1980): Effects of various combinations of oil spraying, washing, sanitizing, storage time, strain, and age of layer upon albumen quality changes in storage and minimum sample sizes required for their measurement. Poult Sci, 59, 2237-2242.

15. Karkulín D (2006): Comparison of production and egg quality parameters of laying hens housed in conventional and enriched cages. Proceedings of EPC, 10-14.

16. Ledvinka Z, Zita L, Klesalová L (2012): Egg quality and some factors influencing it: a review. SAB, 43, 46-52.

17. Onbașilar EE, Avcılar ÖV (2011): The effects of age and oviposition time on egg weight and shell quality of brown layer. Lalahan Hayv Arașt Enst Derg, 51, 15-19.

18. Onbaşılar EE, Ünal N, Erdem E, et al (2015): Production performance, use of nest box, and external appearance of two strains of laying hens kept in conventional and enriched cages. Poult Sci, 94, 559-564. 
19. Onbaşılar EE, Ünal N, Erdem E (2018): Some egg quality traits of two laying hybrids kept in different cage systems. Ankara Univ Vet Fak Derg, 65, 51-55.

20. Pohle K, Cheng HW (2009): Comparative effects of furnished and battery cages on egg production and physiological parameters in White Leghorn hens. Poult Sci, 88, 2042-2051.

21. Réhault-Godbert S, Guyot N, Nys Y (2019): The golden egg: Nutritional value, bioactivities, and emerging benefits for human health. Nutrients, 11, 684.

22. Short FJ, Walker AW, Elson A (2001): Eggshell density in furnished cages: effect of dustbath and perch provision. Brt Poult Sci, 42, 77-78.

23. Tůmová E, Ebeid T (2005): Effect of time of oviposition on egg quality characteristics in cages and in a litter housing system. Czech J Anim Sci, 50, 129-134.

24. Tůmová E, Ledvinka $\mathbf{A Z}$ (2009): The effect of time of oviposition and age on egg weight, egg components weight and eggshell quality. Arch Geflugelkde, 73, 110-115.
25. Tůmová E, Zita L, Hubený M, et al (2007): The effect of oviposition time and genotype on egg quality characteristics in egg type hens. Czech J Anim Sci, 52, 26-30.

26. Yalçın SS, Yalçın S (2013): Poultry eggs and child healtha Review. Lohmann Inf, 48, 3-14.

27. Yalçın S, Yalçın S, Onbaşılar İ, et al (2014): Effects of dietary yeast cell wall on performance, egg quality and humoral immune response in laying hens. Ankara Univ Vet Fak Derg, 61, 289-294.

28. Yalçın S, Eser H, Onbaşılar I, et al (2016): Effects of dietary sepiolite on performance, egg quality and some blood parameters in laying hens. Ankara Univ Vet Fak Derg, 63, 25-29.

29. Yenice G, Kaynar O, Ileriturk M, et al (2016): Quality of eggs in different production systems. Czech J Food Sci, 34, 370-376.

30. Yenilmez F, Uruk E, Serbester U, et al (2017): Effects of wholesaler and consumer conditions on egg quality parameters in different seasons. Çukurova Tar Gıda Bil Derg, 32, 61-68. 